\title{
Covid Reinfection versus Asymptomatic Carrier State: A Case Report
}

\author{
Joy C. Ekezie ${ }^{1 *}$, Tanya Rogo ${ }^{2}$. \\ ${ }^{1}$ Department of Pediatrics, BronxCare Health System, New York, USA. \\ ${ }^{2}$ Division of Infectious Disease, Department of Pediatrics, BronxCare Health System, Bronx, New York, USA.
}

*Corresponding author: Joy C. Ekezie, Department of Pediatrics, BronxCare Health System, Bronx NY, USA.

Received date: July 17, 2021; Accepted date: Augusł 25, 2021; Published date: September 15, 2021.

Citation: Joy C. Ekezie, Tanya Rogo (2021), Covid Reinfection versus Asymptomatic Carrier State: A Case Report, J. New Medical Innovations and Research, 2(5): DOI: 10.31579/2767-7370/023.

Copyright: (C) 2021 Joy C. Ekezie. This is an open-access article distributed under the terms of The Creative Commons Attribution License, which permits unrestricted use, distribution, and reproduction in any medium, provided the original author and source are credited.

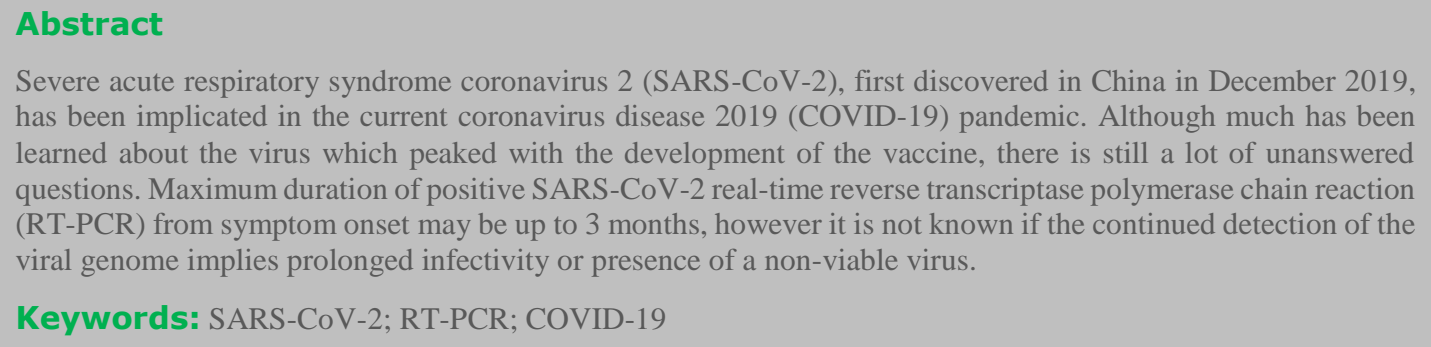

\section{Introduction}

Severe acute respiratory syndrome coronavirus 2 (SARS-CoV-2), first discovered in China in December 2019, has been implicated in the current coronavirus disease 2019 (COVID-19) pandemic. Although much has been learned about the virus which peaked with the development of the vaccine, there is still a lot of unanswered questions. Maximum duration of positive SARS-CoV-2 real-time reverse transcriptase polymerase chain reaction (RT-PCR) from symptom onset may be up to 3 months [1], however it is not known if the continued detection of the viral genome implies prolonged infectivity or presence of a non-viable virus [2]. Most people with COVID-19 develop antibodies after resolution of acute infection [2]. The exact duration of these antibodies in the body is unknown, but some studies have shown that both memory T-cells and Bcells can persist up to 6 to 8 months after acute SARS-CoV-2 infection [3]. These SARS-CoV-2 antibodies may confer some immunity to the person after the acute infection and have been associated with protection against subsequent infection in nonhuman primates by the same viral strain during the early recovery phase [4]. In humans, however, it is unknown to what extent this immune response indicates a protective immunity to subsequent infection with SARS-CoV-2 [5]. Few cases of reinfection have been documented worldwide with varying symptom severity; the first case in the US was published in January 2021 (reinfection occurred in June 2020) [5]. None of the initial cases reported the presence of SARS-CoV-2 antibodies at the time of reinfection. We present a patient who tested positive to SARS-CoV-2 RT-PCR twice in 10 months (Table 1). At both times, she was asymptomatic and the second time, she had coexisting SARS-CoV-2 antibodies.

\section{Case Presentation}

A 39-year-old healthy female healthcare professional in New York City had severe myalgia, generalized body weakness, cough, and subjective fever (maximum axillary temperature 99.8F) in March of 2020. The patient was not tested initially because there was no documentation of fever $\geq 100 \mathrm{~F}$ (which was part of the testing criteria for COVID-19 at that time), in addition to restriction of testing due to limited availability. Conservative management with analgesics and hydration was done and symptoms subsided after 7 days. One week later (April 2020), multiple family members became sick with COVID-like symptoms and had positive SARS-CoV-2 RT-PCR. At this time, patient's symptoms had resolved but she was required to screen for COVID-19 due to close household contact with positive cases. She tested positive for SARSCoV-2 by PCR (Roche Cobas 6800) (Table 1). 


\begin{tabular}{|l|l|l|}
\hline Date & Reason for SARS-CoV-2 testing & SARS-CoV-2 testing done \\
\hline March 18, 2020 & $\begin{array}{l}\text { Severe myalgia, generalized body weakness, } \\
\text { cough, and subjective fever. }\end{array}$ & $\begin{array}{l}\text { Testing not done because patient did not meet } \\
\text { testing criteria at that time (fever }<100 \text { F). }\end{array}$ \\
\hline April 3, 2020 & $\begin{array}{l}\text { Multiple symptomatic family members tested } \\
\text { positive for COVID-19. }\end{array}$ & SARS-CoV-2 RNA RT-PCR ${ }^{2}$ positive. \\
\hline May 26, 2020 & $\begin{array}{l}\text { Voluntary SARS-CoV-2 antibody screening } \\
\text { offered to hospital staff. }\end{array}$ & SARS-CoV-2 IgG positive. $^{3}$ \\
\hline September 11,2020 & Annual employee health screening. & SARS-CoV-2 IgG positive. $^{3}$ \\
\hline January 7, 2021 & $\begin{array}{l}\text { Mandatory return-to-work COVID testing after a } \\
\text { week-long vacation out-of-state. }\end{array}$ & $\begin{array}{l}\text { SARS-CoV-2 RNA RT-PCR } \\
\text { SARS-CoV-2 } \text { IgG }^{3} \text { positive. }\end{array}$ \\
\hline January 13, 2021 & $\begin{array}{l}\text { COVID PCR and antibody testing done in an } \\
\text { Urgent Care. }\end{array}$ & $\begin{array}{l}\text { SARS-CoV-2 RNA RT-PCR } \\
\text { SARS-CoV-2 IgG }{ }^{4} \text { positive. }\end{array}$ \\
\hline February 9, 2021 & $\begin{array}{l}\text { Mandatory COVID screening for clinical rotation } \\
\text { in another hospital. }\end{array}$ & $\begin{array}{l}\text { SARS-CoV-2 RNA and Influenza A and B } \\
\text { Qual NAAT }{ }^{5} \text { negative. }\end{array}$ \\
\hline
\end{tabular}

Table 1: Timeline for SARS-CoV-2 testing

1. New York City Department of Health and Mental Hygiene. 2020 Advisory \#8 COVID-19 Update for New York City https://www1.nyc.gov/assets/doh/downloads/pdf/han/advisory /2020/covid-19-03202020.pdf

2. COBAS-6800 (Roche)

3. Cobas Elecsys (Roche)

4. Alinity i (Abbott)

5. Cobas (Roche)

Routine COVID-19 antibody testing (Roche Cobas Elecsys) offered to hospital staff on a voluntary basis a month later was also positive. Four months later (September 2020) during routine annual employee health screening, her COVID-19 antibodies were rechecked and were still reactive. In January 2021, the patient was tested due to mandatory returnto-work screening required after out-of-state travel and was found to be positive by both PCR and antibody. At that time, patient was completely asymptomatic but was required to quarantine. Six days later, she repeated both tests in an urgent care facility at which time SARS-CoV-2 RNA PCR (Roche Cobas) was negative while the IgG antibodies (Abbott Alinity i) remained positive. A respiratory viral panel for SARS-CoV-2 RNA PCR and influenza A and B (Roche Cobas) done three weeks later as part of the prerequisites for clinical rotation in a different hospital was also negative.

\section{Discussion}

Millions of cases of SARS-CoV-2 infection have occurred worldwide, however only a few cases of reinfection have been reported. The asymptomatic index case had antibodies at the time she re-tested positive for SARS-CoV-2 10 months after first testing positive. This may be a case of re-infection in which the presence of antibodies kept the patient symptom-free. Genomic sequencing for the virus was not done on both occasions, nor does she have a negative PCR test between April 2020 and January 2021. Therefore, it is unclear if she had been carrying viral particles in her nose for 10 months. It is also unclear if she was contagious, as detecting viral RNA after recovery does not mean that there is infectious virus present [1]. Also, the last two SARS-CoV-2 RNA PCR tests done were negative so it may be inferred that, similarly, she may have been negative after the first infection even though she was not rechecked.

\section{Conclusion}

In conclusion, this report raises some unanswered questions which include:

1. Does testing positive to SARS-CoV-2 PCR while asymptomatic and having antibodies mean that the person is infectious?

2. What is the duration and durability of protection from neutralizing SARS-CoV-2 antibodies? Should checking of antibodies include quantitative titers?

3. What is the maximum duration an individual can have detectable SARS-CoV-2 viral RNA after infection?

We hope that further research will address these questions soon. Meanwhile, we recommend that continued precautions should be taken by everyone until herd immunity to SARS-CoV-2 has been achieved.

\section{Acknowledgement}

The authors wish to acknowledge Dr. Murli Purswani and Dr. Roy Vega who made substantial input to the work.

\section{Declaration}

\section{Funding: None}

Ethics approval: Ethical approval was waived by the Institutional Review Board of BronxCare Health System as the report involved less than five patients.

Consent for publication: Consent was obtained from the patient and de-identified data was used.

Conflict of interest: The authors have no conflict of interest to declare.

Authors' contributions: The first author drafted the article while the second author critically reviewed it.

\section{References}

1. Henderson DK, Weber DJ, Babcock H, Hayden MK, Malani A, Wright SB, et al (2021). The perplexing problem of persistently PCR-positive personnel. Infect Control Hosp Epidemiol; 42(2):203-204.

2. Wajnberg A, Mansour M, Leven E, Bouvier NM, Patel G, FirpoBetancourt A, et al (2020). Humoral response and PCR positivity 
in patients with COVID-19 in the New York City region, USA: An observational study. The Lancet Microbe; 1(7):e283-289.

3. Dan JM, Mateus J, Kato Y, Hastie KM, Faliti CE, Ramirez SI, et al (2021). Immunological memory to SARS-CoV-2 assessed for greater than six months after infection. Science. doi:10.1126/science.abf4063.
4. Chandrashekar A, Liu J, Martinot A, McMahan K, Mercado NB, Peter L, et al (2020). SARS-CoV-2 infection protects against rechallenge in rhesus macaques. Science; 369(6505):812-817.

5. Tillett RL, Sevinsky JR, Hartley PD, Kerwin H, Crawford N, Gorzalski A, et al (2021). Genomic evidence for reinfection with SARS-CoV-2: A case study. The Lancet Infectious Diseases; 21(1):p52-58.
This work is licensed under Creative Commons Attribution 4.0 License

To Submit Your Article Click Here: Submit Manuscript

DOI: $10.31579 / 2767-7370 / 023$
Ready to submit your research? Choose Auctores and benefit from:

* fast, convenient online submission

* rigorous peer review by experienced research in your field

* rapid publication on acceptance

* authors retain copyrights

* unique DOI for all articles

* immediate, unrestricted online access

At Auctores, research is always in progress.

Learn more auctoresonline.org/journals/new-medical-innovations-andresearch 